\title{
The development of a probing prompting-based student worksheet to improve fourth grade students' critical thinking ability
}

\author{
Putri Permatasari ${ }^{1^{*}}$ \\ Pramudiyanti $^{2}$ \\ Alben Ambarita ${ }^{3}$ \\ Lilik Sabdanintyas ${ }^{4}$ \\ ${ }^{1}$ Master's Program in Primary Education, Universitas Lampung, Bandar Lampung, Indonesia \\ ${ }^{2-4}$ Department of Primary Education, Universitas Lampung, Bandar Lampung, Indonesia
}

\begin{abstract}
This study aims to develop a probing prompting-based student worksheet to improve students' critical thinking skills. The research followed the Borg \& Gall research and development model, conducted at SD Negeri 1 Metro Timur, Metro City, Lampung, Indonesia. This research adopted a purposive sampling technique with a total of 46 students divided into 23 students in the experimental class and 23 students in the control class. The research data collection techniques were obtained using questionnaires, documentation, and learning outcomes tests. The results showed that the probing prompting-based student worksheet developed was feasible, interesting, easy, useful and effective to use. Finally, the findings have implications and limitations for future research.
\end{abstract}

\section{KEYWORDS}

Student worksheet; research and development; critical thinking

Received: 26 January 2022

Received: 09 February 2022

Published: 11 February 2022

\section{Introduction}

Education has an important role in human life because it is a vehicle for creating quality human resources both in terms of knowledge and skills. In this modern era, education plays an important role in creating a generation that is able to keep pace with the pace of development of science and technology. According to Bailik (2015) in order to keep pace with the pace of development of science and technology, critical thinking skills, communication, creativity, and collaboration are needed for students in the 21st century.

Students are required to be able to develop abilities that focus on developing higher thinking skills, one of which is by improving critical thinking skills. This is also supported by Carlgren (2013) which states that critical thinking skills are one of the most important abilities to develop as citizens in the 21st century. Individuals are often faced with making decisions that require reasoning, understanding, analysis and evaluation of the information received, so that critical thinking allows a person to make valid decisions.

The potential of students will emerge when assisted with a number of teaching materials or tools that support the interaction process carried out. One of the teaching materials used by educators to support the learning process is the use of Student Worksheets (LKPD). According to Prastowo (2015) LKPD is printed teaching materials in the form of sheets of paper containing material, summaries, and instructions for implementing learning tasks that must be done by students, which refers to the basic competencies that must be achieved. LKPD contains activities that contain the stages that students must do in finding concepts. LKPD is one form of teaching material that is often used by educators in conveying learning topics. LKPD itself contains material or questions or assignments that must be completed by students. LKPD can be useful in many ways, such as helping to construct student knowledge, besides that LKPD can attract interest when combined with learning models. This is in line with research conducted by Elsa, (2017) which shows that in the learning process using the probing prompting model can improve students' critical thinking skills and increase student activities and activities in the learning process. Furthermore, research conducted by Ajeng (2013) showed that the effect of the probing prompting learning model assisted by the worksheet showed that the experimental group students who were taught using the probing prompting worksheet succeeded in improving learning outcomes compared to the control class taught using the probing prompting learning model. conventional models. 
There are several studies that are relevant to this research study, namely, research conducted by Sadeghii \& Malekian (2014) shows the results that all learning carried out in creative representation is effective in improving critical thinking skills of third grade elementary school students. in the aspects of making conclusions, identifying deduction assumptions, explaining and interpreting, and evaluating. Furthermore, Semmar \& Fakhro (2009) found that there are significant differences in the practice of critical thinking learning between educators in independent schools and public schools. The independent school emphasizes a learner-centered curriculum that makes a strong contribution to collaborative learning and the creation of experimental learning activities inside and outside the classroom. This shows that the pedagogic practices used by independent school educators tend to be more enriching in terms of fostering students' critical thinking skills.

Research conducted by Pujiyanti (2018) shows that the development of physics handouts with the probing prompting model is able to improve student learning outcomes and critical thinking skills seen from the validation value of standard gain values in the pretest and posttest shows that physics material with the probing prompting model is in the very category. good. The learning steps using the probing prompting model are as follows: 1) Facing new situations, 2) Giving opportunities to think, 3) Asking questions, 4) Giving opportunities to think, 5) Appointing students, 6) Asking final questions (Mutmainnah \& Napitupulu, 2016).

Then, Utami (2016) showed that learning geography by using LKS got a very good response from students. This is indicated by the activeness of students in expressing opinions, asking questions, discussing in groups. The data, pictures and maps on the worksheets also attract students' attention in learning geography. Meanwhile, research conducted by Toman (2013) with the results of his research shows that LKPD can make learning more interesting and fun, as well as provide feedback and can improve higher-order thinking skills.

The first and second studies are about the importance of having critical thinking skills to develop ideas and ideas that can produce many alternative solutions. While the third and fourth studies are descriptive of the effectiveness of using the probing prompting model with the steps 1) Facing new situations, 2) Giving opportunities to think, 3) Asking questions, 4) Giving opportunities to think, 5) Appointing students, 6) Asking questions. end. The fifth and sixth studies are studies that show the use of LKPD in the learning process can help students find lesson concepts easily.

Based on the description above, the researchers are interested in conducting research on the development of worksheets based on the probing prompting model to improve students' critical thinking skills. The purpose of this research is to see how the feasibility, attractiveness, convenience, usefulness and effectiveness of product.

\section{Literature review \\ Student worksheet}

LKPD is one of the teaching materials that has an important role in learning activities. According to Ozmen \& Yildirim (2011) LKPD is a sheet that contains work or material that makes students more active in taking meaning from the learning process. Furthermore, according to Choo et al. (2011) LKPD is a learning tool consisting of a series of questions from information designed to guide students to understand complex ideas as they work systematically. LKS in the learning process is useful as a guide for understanding learning materials.

The purpose of making LKPD according to Lee (2014) explains that the purpose of educators using LKPD is to support learning, encourage active learning in the classroom. LKPD contains questions that can attract students' interest when paired with teaching methods. LKPD is used by educators to understand students' prior knowledge, learning outcomes, and monitor student learning progress. So it can be concluded that LKPD has the purpose and benefit of providing convenience for students in understanding the subject matter, helping students to be actively involved in learning and training students' independence in working on questions.

\section{Investigate pushing}

Learning activities are educational processes that provide opportunities for students to develop their potential into increasing abilities. According to Shoimin (2014) suggests that a learning model that develops the potential of students, one of which is probing prompting which is this learning model by means of educators presenting a series of questions that are guiding and exploring so that there is a thinking process that links the knowledge and experiences of students with new knowledge. being studied. Then, Suherman (2008) states that probing prompting is a learning model in which educators present a series of questions that explore and guide so that a thought process occurs that links each student's knowledge and experience with the new knowledge learned. Furthermore, students construct concepts, principles, and rules into new knowledge so that new knowledge is not notified

Probing prompting consists of two very closely related processes. To investigate literally means to dig. Meanwhile, according to the term probing means trying to obtain clearer or more in-depth information. Suherman et al. (2001) explained that probing questions are questions that explore to get further answers from students to develop the quality of the first answer so that subsequent answers are clearer, more accurate and make sense.

Jacobsen, et al (2009) state that through the probing process, educators try to make students justify or at least explain further about their answers, this way can increase the depth of discussion. To invite literally means to direct or guide. Meanwhile, according to the term, questions are questions that are asked to provide direction to students in their thinking process. 


\section{Critical thinking}

Thinking is an activity that humans always do. Critical thinking is an ability that needs to be trained and developed in students. This is also supported by the opinion stated by Carlgren (2013) that the ability to think critically is one of the most important abilities to develop as a citizen in the 21st century. This is supported by Aizikovitsh-Udi \& Cheng (2015) which states that critical thinking skills are important and must be possessed by individuals. Individuals are often faced with making decisions that require reasoning, understanding, analysis and evaluation of the information received, so that critical thinking allows a person to make valid decisions.

According to Ennis in Fisher (2009) argues that critical thinking is a thinking process that aims to make reasonable decisions, so that what is thought is the best of the truth that can be done correctly. Critical thinking is related to the cognitive dimension. This is in line with the opinion of Facione (2013) stating that critical thinking contains a cognitive dimension which is an indicator of critical thinking. Facione divides the critical thinking process into six skills, namely interpretation, analysis, evaluation, inference, explanation, and self-regulation.

Facione (2013) stated that someone who is said to think critically does not have to fulfill all aspects of critical thinking dimensions such as critical thinking skills. So to see the ability to think critically one can choose one of several aspects of these dimensions according to the focus of the discipline to be studied. According to Yaumi (2012) the dimensions and indicators of critical thinking skills developed in elementary schools need to be simplified and adapted to the cognitive level which is still at the concrete operational stage investigated.

\section{Methods}

The development procedure in this study refers to the theory of Borg \& Gall (1983). The Borg \& Gall model has the following steps: 1) research and information collection, 2) planning, 3) development of the initial form of the product), 4) Desk Evaluation, 5) revision of the main product, 6) main field trial, 7) operational product revision, 8) operational field test, 9) final product revision, and 10) dissemination and implementation.

In accordance with the ten steps of implementing research and development, in this study the researcher only carried out steps one to seven, namely Research and information gathering (introduction) to revision of Operational products (final product based on input from the main field test). Steps eight to ten were not carried out due to time constraints and expensive costs for developing research products and this was indeed carried out in accordance with research standards for thesis needs.

\section{Participants}

Determination of research subjects using purposive sampling technique. This research was conducted in fourth grade at SD Negeri Metro Timur, Indonesia. The research subjects were 46 students with an age range of 9-10 years. which was divided into an experimental class $(\mathrm{N}=23)$ with 18 female students and 5 male students and a control class $(\mathrm{N}=23)$ with 17 female students and 6 male students.

\section{Data analysis}

Analyses of the feasibility, attractiveness, convenience, and usefulness of the worksheets were obtained from the results of product validation and student responses which were calculated using the formula:

$$
\mathbf{N}=\frac{\mathbf{R}}{S M} \mathbf{X} 100
$$

The final score is converted to the following scoring criteria.

Table 1. Criteria for the validity of materials, media, language, and expert educators

\begin{tabular}{cl}
\hline Presentation & \multicolumn{1}{c}{ Interpretation } \\
\hline $81 \%-100 \%$ & Very valid, very thorough, usable \\
$61 \%-80 \%$ & $\begin{array}{l}\text { Quite Valid, quite effective, can be used with Minor } \\
\text { Improvements }\end{array}$ \\
$41 \%-60 \%$ & Less valid, less effective, incomplete, unused \\
$21 \%-40 \%$ & $\begin{array}{l}\text { Invalid, ineffective, incomplete, unusable } \\
0 \%-20 \%\end{array}$ \\
& $\begin{array}{l}\text { Very invalid, very ineffective, very incomplete, } \\
\text { unusable }\end{array}$ \\
\hline
\end{tabular}

(Akbar, 2013) 
Table 2. Criteria for attractiveness, convenience, and product usability

\begin{tabular}{cccc}
\hline & \multicolumn{2}{c}{ Criteria } & \multirow{2}{*}{ Average } \\
\cline { 1 - 3 } attractiveness & Convenience & Utility & \\
\hline Very interesting & Very easy & Very useful & $3.26-4.00$ \\
Interesting & Easy & Useful & $2.51-3.25$ \\
Less attractive & Not easy & Less useful & $1.76-2.50$ \\
Not attractive & Difficult & Useless & $1.01-1.75$ \\
\hline
\end{tabular}

(Akbar, 2013)

\section{Analysis effectiveness}

The effectiveness of probing prompting -based worksheets to improve students' critical thinking skills was obtained through the pretest and posttest scores. Based on the results of the study, the student scores obtained were then converted into student scores. Then, these results were analyzed by calculating n-Gain with criteria referring to Sundayana (2015) with the formula as follows:

$$
n-\text { Gain }=\frac{(\text { post test })-(\text { pre test })}{\max -\text { pre test score }}
$$

The final score is converted to the following scoring criteria.

Table 3. Criteria for n-gain

\begin{tabular}{c|c}
\hline Get Normalized score & Interpretation \\
\hline$-1.00 \mathrm{~g}<0.00$ & reduce \\
$\mathrm{g}=0.00$ & Constant \\
$0.00<\mathrm{g}<0.3$ & Low \\
$0.30 \mathrm{~g}<0.70$ & Currently \\
$0.70 \mathrm{~g} 1.00$ & Tall \\
\hline
\end{tabular}

(Sundayana, 2015)

To prove the significance of the difference between the two groups, it is necessary to test using the Independent Sample T Test with the following formula.

$$
t=\frac{X_{1}-X_{2}}{\sqrt{\frac{\left(n_{1}-1\right) S_{1^{2}}+\left(n_{2}-1\right) S_{2^{2}}}{n_{1}+n_{2}-2}\left(\frac{1}{n_{1}}+\frac{1}{n_{2}}\right)}}
$$

\section{Product eligibility}

The recapitulation of the results of the expert and educator validation assessment can be seen in table 4 .

Table 4. Recapitulation of product validation

\begin{tabular}{clc}
\hline Not & \multicolumn{1}{c}{ Validator } & Score \\
\hline 1 & Material Expert & 88,46 \\
2 & Media Expert & 85.41 \\
3 & Linguist & 86.53 \\
4 & Class IV Teacher & 92.47 \\
\multicolumn{2}{l}{ Average } & 89.80 \\
\hline
\end{tabular}

\section{Attractive, convenience, product use}

The results of the assessment of the attractiveness, convenience and usefulness of the test can be seen in table 5.

Table 5. Results of attractiveness, convenience, and usability of LKPD

\begin{tabular}{clcl}
\hline Not & Test Type & Average & \multicolumn{1}{c}{ Criteria } \\
\hline 1 & attractiveness & 3.88 & Very interesting \\
2 & Convenience & 3.73 & Very easy \\
3 & Utility & 3.81 & Very useful \\
\hline
\end{tabular}




\section{The effectiveness of student worksheet to improve students' critical thinking skills}

Table 6. Comparison of n-gain creative thinking ability of the experimental class and the control class

\begin{tabular}{|c|c|c|}
\hline \multicolumn{3}{|c|}{ Average Experiment Class Control Class } \\
\hline $\begin{array}{l}\text { preliminar } \\
\text { y test }\end{array}$ & 67.39 & 67.54 \\
\hline Posttest & 82.75 & 72.90 \\
\hline N-Gain & 0.47 & 0.17 \\
\hline Criteria & Currently & Low \\
\hline
\end{tabular}

Table 7. Results of t-test

\begin{tabular}{lccc}
\hline t table (0.05) & $\begin{array}{c}\text { Component } \\
\text { don't } \\
\text { count }\end{array}$ & Index & Results \\
\hline 2.01537 & 3.48 & t count $>$ t table & $\mathrm{H}_{0}$ accepted \\
\hline
\end{tabular}

\section{Discussion}

\section{Product eligibility}

Table 4 shows that the average score of 88.46 is included in the very feasible category. The LKS developed follows the LKS requirements (Darmojo, 2012) namely didactic requirements, construction requirements, and technical requirements to become a good and proper LKS. Dictactic requirements, namely requirements that must follow the principles of effective teaching and learning, constructive requirements, namely with regard to language use, sentence structure, vocabulary, level of difficulty and technical requirements are requirements for preparing LKS in terms of writing, pictures, and appearance.

Based on the questionnaire data obtained, it shows that the students' responses were more positive in the experimental group than the control group in the critical thinking aspect. Based on the basis of constructivist learning theory, learning is the result of the construction of students as a result of their interaction with the environment. This is in line with Prastowo (2016) explaining that the flow of constructivism sees students' direct experiences as the key to learning, so students construct their knowledge through interactions with objects, phenomena, experiences, and their environment. Lee (2014) explained that the purpose of educators using LKPD is to support learning, encourage active learning that can attract students' interest when paired with teaching methods. LKPD is used by educators to understand students' previous knowledge, learning outcomes, and monitor student learning progress. Although this LKPD only takes one of the themes and sub-themes in grade IV Elementary School, it still does not reduce the value that this probing prompting-based LKPD is one of the alternative innovations of good teaching materials and can be used in learning. Probing prompting-based LKPD is appropriate to be used as a reference and companion for the development of subject matter contained in the 2013 curriculum student book, because this LKPD is designed and developed referring to the 2013 curriculum. experience for themselves, and obtain information available in the LKPD in the form of text, pictures, illustrations, or activity steps, thus encouraging students to construct knowledge with their own experience.

\section{Attractive, convenience, product use}

Table 5 shows the results of the attractiveness test which consists of five indicators. The results of this research and development show that the probing prompting-based LKPD product developed is attractive, easy, and useful in thematic learning. The probing prompting-based LKPD product developed is in accordance with the LKPD Development steps and has been validated by three experts (material, media, language) and practitioners. The next stage after the researcher conducted a validation test was to revise the product on the suggestions and comments of the validator.

Based on the attractiveness test given to 9 students, a score of 3.88 was obtained with a very interesting category. The ease test obtained a score of 3.73 with a very easy category and the usefulness test obtained a score of 3.81 with a very useful category. Students find it easy to understand the content of the material by using LKPD based on probing prompting and are motivated to learn thematic learning.

This shows that the LKPD based on probing prompting is feasible to be studied independently by students; they find it interesting, easy and helpful. This is in line with research of Sari et al. (2018) which states that student responses to the use of developed worksheets show good results. Supported by Sugiyanto (2009) the learning model can focus on the quality and meaningful interactions and emphasize the meaning and quality of the learning process.

\section{The effectiveness of student worksheet to improve students' critical thinking skills}

The effectiveness test was obtained from the results of the pretest and posttest given to the experimental class and control class. Next, the average N-Gain for each class is searched. The results of increasing students' creative 
thinking skills can be seen in table 6 . To prove the significance of the difference between the experimental class and the control class, it is necessary to do a test using the Independent Sample $\mathrm{T}$ Test. The test criteria are if $\mathrm{t}$ count $\mathrm{t}$ table with $=0.05$ then Ha is accepted. And vice versa if $t$ count $<t$ table then Ha is rejected. The results of testing the hypothesis of creative thinking abilities can be seen in table 7 . Based on calculations with Df $=44$ and a significance level of $0.05(5 \%)$, the results of $\mathrm{t}$ arithmetic $=8.14$, while $\mathrm{t}$ table $=2.006$. It is known that $\mathrm{t}$ arithmetic $>\mathrm{t}$ table $=3.48$ $>2.01537$, so it can be said that Ho is rejected and Ha is accepted. It can be concluded that there are differences in the effectiveness of creative thinking skills using LKPD based on probing prompting and those not using LKPD. This is in line with research conducted by (Elsa, 2017) which shows that in the learning process using the probing prompting model can improve students' critical thinking skills and increase student activities and activities in the learning process.

\section{Conclusion}

Based on the results of research and development that has been carried out with the title "Development of probing prompting-based LKPD to improve critical thinking of fourth grade elementary school students" it can be concluded that the developed LKPD is feasible, interesting, easy and effective to be reviewed based on the results of validation and questionnaires that have been carried out.

Based on the research results, the development of LKPD based on probing prompting has several limitations, namely as follows: (1) The development of this product only includes one sub-theme of the three sub-themes in theme 2 (Always Save Energy). (2) This research and development only reached the seventh step of the ten steps of Borg and Gall's research and development. (3) The research population is only in one cluster, namely educators and fourth grade students, Cut Nyak Dien Cluster, East Metro District. (4) The attractiveness, convenience and usefulness test is limited to only 9 students. (5) The probing prompting-based LKPD effectiveness test is carried out online due to the conditions of the Covid-19 pandemic.

\section{Acknowledgements}

The researchers would like to thank the University of Lampung for supporting researchers to conduct this research.

\section{Funding}

This research did not receive a special grant from any public, commercial, or non-profit funding agency sector.

\section{References}

Ajeng, D. (2013). The effect of assisted probing prompting learning model structured worksheet there are learning outcomes. Journal of Chemical Education Innovation. 7 (1). 1106-1110.

Aizikovitsh-Udi, E., \& Cheng, D. (2015). Developing critical thinking skills from dispositions to abilities: Mathematics education from early childhood to high school. Creative education. 6(04), 455.

Akbar, S. (2013). Learning Tool Instruments. Bandung: Rosdakarya.

Baikik, M \& Fadel, C. (2015). Skills for the 21st Century. Boston: Curriculum Redesign Center.

Borg, WR \& Gall, MD (1983). Edication research: An introduction fifth edition. New York: Longman.

Carlgren. ( 2013 ). Communication, critical thinking, problem solving: A recommended course for all high school students in the 21st Century. Spring Science. 4 (4). 63-81.

Choo, Serene SY et al. (2011). The Effect of Worksheet Scaffolds on Student Learning in Problem-Based Learning. Journal of Adv in Health Science Education. 16. 517-528.

Darmojo. (2012). Science education. Homemade: Press Diva.

Elsa, S. (2017). The application of the Probing-Prompting Learning Model to improve the mathematical critical thinking skills of Class XI Science Man 1 students in Bengkulu City. Raflesia's journal of mathematics education. 2 (1). 102-104.

Facione, PA (2013). Critical thinking expert consensus statement for the need for educational assessment and instruction of research results and recommendations. California: California State University Fuerton.

Fisher, Alec. (2009) . Critical thinking an introduction. Jakarta: Erlangga.

Jacobsen, et al. (2009). Teaching methods (teaching methods). Yogyakarta: Learning Library.

Lee, Che Di. (2014). Use of Worksheets on Reading Achievement, Lack of Class Readiness, and Cross-Country Comparative Science Achievement. International Journal of Education in Mathematics, Science and Technology. 2 (2). 96-106.

Mutmainnah, S., Ali, M., \& Napitupulu, ND (2016). Application of probing-prompting learning techniques to improve physics learning outcomes in class VIIIA students of SMP Negeri I Banawa Tengah. JPFT (Journal of Physics Education Tadulako Online). 2 (1), 38-43.

Ozmen \& Yilrim. (2011). The Influence of Student Worksheet on Student Success: Acid and Sample-Based. Turkish Journal of Education. 2(2). 4

Prastowo. (2015). A creative guide to making Innovative Teaching Materials. Yogyakarta: Diva Press.

Pujiyanti, P. (2018). Development of physics handout using guided inquiry method with probing prompting technique to improve learning outcomes and critical thinking ability of high school students. Journal of Mathematics and Science education. 7 (2). $115-117$

Sadeghii, S., \& Malekian, F. (2014). Examine the role of education through curriculum development, creative and critical thinking view elementary third grade. Journal of Educational \& Instructional Studies in the World. 4(4). 
Shoimin, Aris. (2014). 68 Innovative Learning Models in the 2013 Curriculum. Yogyakarta: Ar-Ruzz Media.

Semmar, Y., \& Fakhro, A. (2009). Investigating Critical Thinking Skills Practices in Qatari Elementary Schools. International Journal of Learning. 16(1).

Sugiyanto. (2009). Innovative learning model. Surakarta: FKIP UNS Regional Teacher Certification Committee.

Suherman, Eman et al. (2001). Contemporary mathematics learning strategies. Bandung: Jica.

Suherman, Erman. (2008). Learning and learning mathematics. Bandung: not published.

weekly. (2015) . Learning evaluation. Bandung: Alphabet.

Toman, U. (2013). Extended worksheet developed according to 5E model based on constructivist learning approach. International Journal. Postgraduate University. 4. 173-183.

Utami, WS. (2018). Development of LKPD based on problem based learning to improve the creative thinking ability of high school students in learning geography for class XI IPS. Surabaya State University. 1(1).

Utami, WS. (2016). The effectiveness of geography student worksheet to develop learning experiences for high school students. Journal of Education and Learning, 5(3), 315-321.

Yaumi, Muhammad. (2012). Multiple intelligences-based learning. Jakarta: People's Diane. 